\title{
3. Community informatics and the power of participation
}

\section{A ABSIRACII}

This article discusses the potential of information and communication technology (ICT) for social capital and community empowerment in Pacific societies through case studies of internet use by online communities during various political crises in Fiji and emerging community media. It argues that despite being located on the fringe of the ICT boom, it is still possible for island communities to engage with media technology using participatory approaches to develop local content which is closer to their own realities and which reflects local cultures, values and individual aspirations.

\section{USHA SUNDAR HARRIS}

Macquarie University, Sydney

\section{Introduction}

Thformation and communication technology (ICT) offers a powerful way of inviting wider representation of people's voices and views which

are necessary for democratic participation. Governments in developing countries see the adoption of new technologies such as the internet as a panacea for their nations' economic ills and essential in creating prosperous information societies. But to harness the full potential of ICT, it is imperative that communities, including the most marginalised, have meaningful engagement with the relevant technology to be able to effectively express their needs and aspirations.

Unequal access to ICT remains the greatest challenge. While the internet has been successfully adopted within the commercial and public service sectors, it is still virtually untapped at the community level in many Pacific island nations. Thus the digital divide exists not only between nations but also within nations where disadvantaged groups have the least access 
to ICT. In his discussion of technology and society, Castells points out: 'Technology does not determine society. Nor does society script the course of technological change $[. .$.$] the final outcome depends on a complex pattern$ of interaction' (2000, p. 5).

This article argues that Pacific island communities can interact with various forms of ICT at a local level, using participatory approaches, to develop content which is closer to their own realities and which reflect local cultures, values and individual aspirations. The process of local content production not only empowers the individual, it fosters community engagement, creates social capital and builds communities.

\section{Participatory media and community empowerment}

Traditional communities have hierarchical social structures, but the modernising influences of global media, universal education, individual economic power and democracy mean that subordinate groups, which include women and youth, are striving for greater representation of their views in the nation's development. However, traditional structures either lack or have dysfunctional transactional mechanisms, such as some cultural practices, which prohibit communication between the powerful and the powerless. For example, practices where women or the young cannot speak or even appear in the presence of a senior kin or chief exist in some Pacific cultures. Lack of literacy tools also exacerbates this situation. When people communicate from a disempowered position their voices become lost or misrepresented by those who mediate on their behalf. In this environment, bottom-up channels of communication become necessary so that those who have the least amount of power can be heard.

Participatory media enable people to produce and distribute content according to their own needs without going through the traditional gate keepers. Emanating from the theoretical discourse in participatory communication (Servaes, White \& Jacobson, 1996; White, Nair \& Ascroft, 1994) participatory methodology is people-centred, process-oriented and contextualised in a local setting using local knowledge. Participation of communities in message-making is essential. It is important to point out that within this concept the process of production (rather than the finished product) is central to the empowerment of individuals.

Two of the most effective forms of communication in this regard have been the media of radio and video which have the capacity to bring the voices

30 PACIFIC JOURNALISM REVIEW 13 (2) 2007 
of marginalised groups into the public sphere (Dagron, 2001; Satheesh, n.d.; White, 2003). The internet has also become an important way of expressing opinions through online discussion lists, blogs and emails in societies where it is easily accessible (Meikle, 2002). When people are able to express exactly what they want to say, they become engaged in a powerful empowering act. This ability for self-representation eventually leads them to reflect on the power relationships 'within their specific social structures and cultural contexts, as well as those imposed from without' (Braden, 1999, p. 118). A World Bank study supports this view:

In 2000, the World Bank carried out the largest-ever survey to determine what people living in poverty said they wanted and needed most. The most common response was that people's first priority was not money. Instead, what they needed is a voice - a say —in decisions that affect them. (Deane, 2005, p. 2)

There is a difference between knowledge and information. While the former is situated within the realm of enlightenment and betterment of society and is transformative in nature, the latter is an accumulation of data. Information becomes knowledge when it makes a qualitative difference to the lives of those engaged in its adoption. Does this information have value for me? Is it going to change me or my community in any meaningful way? In other words, it must have a development potential resulting in an improved quality of life. To use Nepalese journalist Kunda Dixit's words: ‘... To be useful, information must help people communicate, participate and allow them and their rulers to make informed choices' (2000, p. 1).

In Australia, a discussion paper prepared by the Department of Communications, Information Technology and the Arts noted: 'As the use and impact of ICT increases, so does the prospect that ICT can play a role in shaping the nature of community development and contributing to the building of social capital'. Case studies, undertaken as part of the project, indicated that it was largely untapped and unrecognised in many areas (2005, p. 1).

\section{Social capital - a definition}

Since the 1980s modern theories of civil society and community building especially in the West have been theorised in ideas of social capital (Bourdieu 1983; Coleman, 1988; Putnam, 2000) and have been aligned to 
a range of fields such as sociology, education, political science and towards sustainable human and economic development. The World Bank definition of social capital is framed around the development agenda:

Social capital refers to the institutions, relationships, and norms that shape the quality and quantity of a society's social interactions. Increasing evidence shows that social cohesion is critical for societies to prosper economically and for development to be sustainable. Social capital is not just the sum of the institutions which underpin a society-it is the glue that holds them together. (World Bank, n.d.)

Robert Putnam (2000) gave the term common currency when he used it to explain the decline in civic engagement in American society and the resultant loss of social capital. He identified the 'technology of mass media', specifically television viewing of entertainment programmes, as the main reason for this loss. He defined social capital as 'connections among individualssocial networks and the norms of reciprocity and trustworthiness that arise from them' (ibid, p. 19). Putnam also discussed two important dimensions of social capital-bonding and bridging networks. While bonding linkages 'tend to reinforce exclusive identities and homogeneous groups' such as ethnic or gender specific groups, bridging social capital links 'are outward looking and encompass people across diverse social cleavages' and thus lean towards inclusiveness and 'can generate broader identities and reciprocity' (ibid. p. 22, 23).

World Bank identifies bonding as horizontal connections and further elucidates:

This view recognises that horizontal ties are needed to give communities a sense of identity and common purpose, but also stresses that without 'bridging' ties that transcend various social divides (e.g. religion, ethnicity, socio-economic status), horizontal ties can become a basis for the pursuit of narrow interest, and can actively preclude access to information and material resources that would otherwise be of great assistance to the community (e.g tips about job vacancies, access to credit). (World Bank, n.d.)

\section{ICT in Pacific Island societies}

Pacific Island nations together make up a population of 8.5 million, or less 
than 0.01 percent of the world's population. The islands are among the last places on earth to receive television and internet access. In a global environment of commercialisation and consumerism, how do small nation states with insignificant populations harness ICT for their own benefit? An International Telecommunication Union (ITU) document on the needs of small island developing states (SIDS) noted that various international conferences recognised that well developed telecommunications/ICT infrastructures, which are easily accessible and affordable, was important 'to this group of countries in poverty alleviation, provision of services in government, business and the community' (ITU, 2007).

In an attempt to improve their telecommunications capability and diversify their economies Pacific Island Forum countries have signed a memorandum of understanding confirming interest in connecting to a submarine fibre optic cable to replace satellite ones, which most Pacific Island countries rely on currently (Samoa Observer, 10 June 2007). Once in operation various arms of the network would connect groups of islands eg. Fiji, Wallis and Futuna, Samoa, American Samoa and Tahiti in one section and New Caledonia, Vanuatu and Solomon Islands in another. Decision-makers are confident that connection to fibre optic cable will bring costs down, assist in the resurgence of investment and improve telehealth services (Sagapolutele, 2007).

As a decentralised communication network, the internet holds great promise for a diverse and scattered population. It can facilitate the preservation and sharing of indigenous knowledge, provide an essential network for information and communication exchange amongst the community sector and government agencies, and enable learning and skill-building for the growing youth population. However when new technology arrives in a society, it enters an already existing order of social hierarchies, power relationships and a knowledge base. The adoption of the technology can enhance the position of individuals or groups in the social order and isolate those unable to co-opt it easily for their own benefit. It can widen class, gender and generational gaps. For example, young people are able to interact with new technologies more easily then their parents. Women and rural dwellers, on the other hand, benefit the least from ICT diffusion through lack of access (Joshi, 1998). In developing countries, adoption is further constrained by the fact that the technologies which are introduced have been primarily developed for use in industrialised societies. The frustrations of rural communities, attempting to 
adapt to products which were designed for urban consumers, have been the cause of mirth as well as desperation among local users. The incompatibility of technology, human needs and lack of knowledge and infrastructure in developing countries is exemplified in the following anecdote which the writer first heard in 1980 when working as a journalist for the Fiji Times:

\begin{abstract}
A rural dweller, Jone, arrives in the city of Suva to visit his niece. In the morning, when he awakes, his niece plugs in the electric kettle to boil some water for tea. Not having seen such technology before, Jone is amazed at this 'miracle'. He decides to buy one and take it home for his wife. Upon his arrival in the village, Jone gathers the clan to show them his new miracle appliance. He takes the kettle out and plugs it into the wall of his thatched bure and they wait... and wait... and wait. Of course, nothing happens because Jone had missed out on one minor detail when he purchased this new technology. He needs electricity to boil his water and his village is still unconnected. Instead of enhancing his position in the clan as an early adopter, this lack of knowledge makes Jone a laughing stock of the village.
\end{abstract}

Despite Jone's ill-fated interaction with the electric kettle, new forms of technology are being introduced in developing countries every day. Projects such as PFNet in the Solomon Islands and the growing access to telecenters in Samoa provide inspirational models of ICT which have been developed to benefit local communities. PFNet is a network of rural email stations linked by short-wave radios, using laptops and powered by solar energy (Chand \& Leeming, 2006). Establishment of telecenters in rural Samoa has assisted communities to easily access information about remittances sent by family members living overseas instead of having to travel to Apia (Purcell, 2007).

\title{
ICT case studies
}

\section{Internet development in Fiji}

A review of internet development in Fiji provides interesting insights into issues of access and participation. Internet use in Fiji has been growing steadily in recent years in the commercial and government sectors, but is making slow inroads into the domestic market. The first use of internet in Fiji was at the University of the South Pacific (USP) in the late 1980s when it was used for intranet connection. As a result, the domain name .fj, registered 
in 1995, is held by USP, which is responsible for registering all second level domains in Fiji (Minges \& Gray, 2004, p. 28).

The first internet service provider (ISP) was set up by the domestic carrier Telecom Fiji. Internet usage is mainly limited to government and business sectors which were among the first to sign up as customers. Few homes, even in the urban areas, have internet connections. The costs of computers and of ISP connections are beyond the means of many people. One positive area of growth has been the internet cafés which enjoy vigorous business from the youth population. From the author's observation, in urban centres such as Suva and Nadi, more than 70 percent of internet users are young adults and school students who use it for emails, chat lines and to research school projects. Fiji's internet penetration is 2.7 percent or 22,000 connections, mainly in the workplace (ITU, 2003). This represents a growth of 193 percent compared to the 2000 figure of 8000 . The ISP, Connect, estimates that there are 50,000 users in Fiji, raising penetration to 6.1 percent (Minges \& Gray, 2004, p. 12).

Fiji enjoys a well-developed infrastructure compared to its regional neighbours. 62 percent of homes in Fiji are connected to electricity. Remote island communities use generators for power. Just over one third of Fiji's households are connected with fixed telephone lines. The mobile phone penetration rate is 11.4 percent, 90 percent of which are pre-paid customers, based predominantly in urban areas (ibid, p. 8).

In 2000, Fiji was connected to the Southern Cross Cable Network (SCCN) allowing Fiji's international carrier, FINTEL, to offer broadband service for the first time, thus bringing Fiji into the global information infrastructure. Besides its potential to make Fiji the information hub for the South Pacific region, it will also attract commercial investors in the area of IT service, such as call centres and data processing zones, to Fiji (Purcell and Toland, 2003, p. 14).

Major impediments to internet development in Fiji have been unequal telecommunications access between the urban and rural population, prohibitive costs, existence of monopolies and lack of awareness and knowledge of the internet. Pricing is directly related to the telecommunications monopoly held by Telecom Fiji Ltd (TFL) until 2014. Policy makers are aware that computer illiteracy and limited knowledge about the internet will hinder connectivity (J. Turaganivalu, Ministry of Communications, personal communication, 2003). People not only lack the skill to use the technology, but lack an understanding of how it can enrich and enhance the broader community and assist in development. 
The community sector has suffered from a lack of access to technology. In an informal stock-take of its membership, the National Council of Women (NCW) in Fiji found that many of its members 'lack the basic tools for efficient project administration, communication and information dissemination i.e. a computer, a phone or fax machine, let alone internet connection' (Rolls, 2000, p. 13). The NCW is a co-ordinating body for a diverse range of women's groups, clubs and national organisations.

The national secretary, Sharon Bhagwan Rolls, encouraged donors to provide the appropriate technological tools to organisations for the long term to achieve better communication and gender balance in ICT access:

\begin{abstract}
Just as women are being encouraged to pick up a video camera or audio recording equipment to document and produce her-stories, so women need to be encouraged to acquire the knowledge and skills, especially in relation to accessing and using computers and the internet, in order to effectively participate in global advocacy, lobbying and communication networks. This is one way to ensure the women's viewpoints are shared across and throughout all the regions of the globe. (ibid)
\end{abstract}

It is important that this new network accommodate alternative uses of new media encouraging civil society participation and is not largely market-driven in the service of the global economy. Communities worldwide are employing new forms of ICT for political agency and social networking. In his examination of internet activism, Meikle (2002) has explored how communities, locally and globally, have used the internet during times of crisis to effect change. This use of the internet has occurred among both local and diaspora Fijian communities. Having experienced four coups in 19 years, people have increasingly turned to the internet to voice their concern, register their protest or simply to report about political upheavals beyond their control.

\title{
The internet coup - May 2000
}

The civilian coup d'état on 19 May 2000 brought world-wide attention to a small web publisher, Fijilive.com, which provided the only communication link out of Suva during the critical first 48 hours of this crisis. In their attempt to paralyse communication with the rest of the world, the perpetrators had cut the international telephone lines but some internet lines had remained operational. The Fijilive publisher, Yashwant Gaunder, a journalist by 
profession, instantly recognised the power of the internet in maintaining the global communication flow. In an amazing example of reverse news flow, the world's news media took direct feeds off Fijilive.com to inform international audiences about the events unravelling in Fiji's Parliamentary compounds, thus describing it as 'the internet coup'. Gaunder himself was surprised by the interest his website generated worldwide. He recollects the events of 19 May 2000 and how his website became the central channel of information flow out of Fiji:

\begin{abstract}
We were not sure if the people could read the information. At night we started receiving calls from all over the world, people wanting to talk to us, and then we realized that people were surfing or reading Fijilive.com and keeping up-to-date with the news. But it was only around midnight that it really hit home to us what was happening. This is the time when BBC World News comes on and the first story on BBC World TV was the coup in Fiji and staring at us from the television screen was our website. Straight after that it was a nightmare. We were getting calls from all over the world - from Trinidad, from South Africa - people wanted to interview us and find out what was happening. (Y. Gaunder, personal communication, 2003)
\end{abstract}

By this time, the small website had received more than 100,000 hits. Hosted in the US with a limited capacity, the server crashed as soon as it increased to 120,000 hits. The site was re-hosted within 24 hours and its new address was quickly circulated among the online community hungry for the latest political development. Former Fiji residents made up the largest number of loyal visitors to the site followed by local internet users, and a range of individuals, governments and organisations with an interest in Fiji. Other online news sites included Fijivillage.com and Pacific Journalism Online, USP's journalism training website, which provided critical analysis of the coup lacking in other media outlets (Robie, 2001a, 2001b). Unfortunately the major beneficiaries of the online news sites were not the people of Fiji but those living overseas including expatriate Fijians.

\title{
Online community
}

At the time of the 2000 coup there were about 100,000 former Fiji citizens living in a number of the world's metropolitan centres. Numerous web- 
sites sprang up representing diverse views and articulating the concerns of ex-Fiji residents in Canada, the United States, Australia, New Zealand and the UK, creating a transnational diasporic public sphere (Appadurai, 1996). The Indo-Fijian diaspora found a new identity online as a vocal, politically engaged, borderless community. Computer-mediated communication in the form of emails, internet chat rooms and forum postings became central to facilitating a virtual community for dispersed Indo-Fijians who struggled to make sense of yet another coup. During the 1987 coup the Indo-Fijian diaspora relied on community media and social or religious groups to inform and organise political resistance. The May 2000 coup heralded a new form of engagement for a marginalised community which had experienced political exclusion once too often. Large amounts of information flowedsome profoundly insightful, some informative, some full of angst- to create a global support network. Academics in Canberra and Suva, lawyers in Melbourne and London, whole families in suburbs of Sydney, Vancouver and Los Angeles used the world wide web for collective action to voice their concerns, petition their political representatives and seek justice on behalf of their countrymen in Fiji. Indigenous Fijian voices also brought unique insights on issues of nationalism, provincial loyalties and chiefly ambitions. The internet activity was largely uncoordinated and in the aftermath of the coup many of these websites have disappeared. But during the coup the world wide web presented Fiji's dispersed diaspora communities with an invaluable channel of communication and a virtual community shelter in a time of crisis and anxiety.

\section{Coup 2006 - bloggers challenge the military regime}

The military coup led by Commodore Frank Bainimarama in December 2006 heralded another phase of participation on the internet. While various listservs and online discussion groups again served as important channels of information flow, a new word began to find its way in the everyday vocabulary of locals and attract discussion in the media as Fiji-based blogger Chris Hammond-Thrasher noted in his email:

For the first time, 'blog' has become a household word and politically vocal blogs authored by pseudonymed individuals are regularly 
mentioned in international media reports. Anonymous blogging has become perhaps the most popular method of expressing dissent against Fiji's interim government as public forms of dissent have been met with a firm hand by the military. (Hammond-Thrasher, 2007)

Anonymous self-styled 'freedom bloggers' challenged the actions of the regime in their daily blogs and provoked the ire of the military rulers who threatened to block access to the websites. The Fiji government's attempt to censor free speech online and detain suspected bloggers for questioning drew international criticism (ABC Radio Australia, 21 May 2007). Putting aside the political alliances of bloggers, the Fijian experience shows that the internet remains an important network for the expression of alternative viewpoints, and a place of sanctity for freedom of expression and participatory democracy.

\section{Participatory video and the growth of social capital}

The Pacific region is just beginning to recognise the potential of community media, such as radio and small-format video, as a democratising force. Studies of community media in other parts of the world have shown that participatory approaches to production contribute to the extension of social networks (Meadows et al., 2007) and encourage participation in democratic processes by people engaged in what Rodriguez (2001) calls 'citizen's media'. In participatory media production, communities' active involvement is essential in the process of production as opposed to the product-driven video or radio made by professionals in which communities may feature but not participate. As such, local media content is the result of collaborative work within a community of producers as well as with the larger community. The participatory production process calls upon a range of skills, foremost among which is the use of local knowledge and networks, as well as collaboration which engenders trust.

A study, ${ }^{1}$ conducted by the author, of a participatory video production workshop with a group of rural women in Fiji, confirms that participatory media practice not only functions well in communities with strong social networks (i.e. high social capital), but also contributes to the growth of social capital. In other words, it not only accesses local networks-bonding capital — but also extends it by enhancing the bridging dimension of social 
capital where communities can link with other communities across ethnic, gender, social or geographical divides thus contributing to community building and dialogue.

The aim of the research was to undertake an ethnographic study of a participatory video (PV) production project in rural Fiji and examine its implications for community building within the context of Fiji's fractured multicultural society. During the course of the project the author discovered a powerful use of video by the women within a dynamic environment of social relationships and community engagement. A framework for analysis emerged around concepts of social capital and ways in which video production could incorporate and enhance the social capital of rural women by accessing the rich web of rural women's clubs in Fiji. The women were able to apply their social networks to produce video stories which were important to them and their communities. The act of producing the videos meant that women visited each other's communities leading to greater dialog and understanding. The visit created a greater transference of knowledge and cross-cultural understanding. Producing within their local context also allowed the women to integrate the social and cultural values of their own society and develop their own production culture instead of using foreign production values. The involvement of grassroots video producers in video production, in the first instance, was assisted by their social networks in the 'horizontal dimension' (bonding), which in turn, helped to strengthen their networks of influence within the 'vertical dimension' (bridging) thus linking the women to other community groups, as well as people in power including government officials.

\section{Community media in Fiji}

In the past decade there has been a steady growth of community media in Fiji including the now defunct community television station, and several radio stations such as femLINK's radio-in-a-suitcase for women, University of the South Pacific's student Radio Pasifik and Christian broadcasters in various parts of Fiji.

\section{femLINK}

Since its inception in September 2000 femLINK has used various forms of media - print, video and radio - to initiate grassroots participation of women. Although it does not produce participatory video projects in the true sense 
of the term where participants make their own videos, femLINK producers actively incorporate the participants' ideas and reflect their views in the production process. femLINK has produced a series of videos with community stakeholders on a range of topics which is distributed through the grassroots women's network to encourage dialogue among women. femLINK Coordinator Sharon Bhagwan Rolls explains:

We weren't just producing documentaries for broadcast in the mainstream, but our strategy was to then use the community videos as a way to bring women together... to dialogue on the issues that would be raised by women like themselves. So it was serving a purpose of not just creating a space for women to talk and discuss issues, but to also continue the bridge building that is so vitally needed given that the politicians continue to play the race card. (S. B. Rolls, personal communication, 2005).

femLINK also operates a mobile radio-in-a-suitcase project giving airtime to women with disability and rural dwellers. The broadcast takes place on the last Sunday of every month.

\section{Radio Pasifik}

The first community radio licence was given to Radio Pasifik (FM 88.8), the campus radio for students and staff of the University of the South Pacific. It began broadcasting in 1996. In October 2004, the station went online using audio streaming and expanded its Pacific language programming. The station places a high priority on giving airtime to a cross section of island music. This commitment has helped to increase the popularity of Pacific Island bands and the cross promotion of island music in the region according to the station manager, Vili Nadaku:

Last year the buses started playing a Kiribati track and you never hear Kiribati songs being played. The Kiribati students came to me and said, 'we're so proud. For the first time we feel like we are part of the university community'...This is a positive outcome of Radio Pasifik. This is part of what we're trying to achieve. (V. Nadaku, personal communication, 2005). 
Radio Pasifik is currently restricted to a 100 watts broadcasting and covers a radius of $10 \mathrm{~km}$ from the campus, but is negotiating for a licence which will allow it to broadcast Fiji-wide using satellite.

\section{CTV Fiji}

The removal of television monopoly to Fiji TV, the only free-to-air service, paved the way for the establishment of a community television station in Fiji. CTV was started by a retired expatriate couple, John and Regina Yates, in response to the high percentage of 'inappropriate' foreign programming on Fiji One (Yates, personal communication, 2003). CTV has produced many hours of informational and educational programming with local volunteers. During the 2000 putsch CTV became an important channel of communication for local people as they called the station's talk back programme to express their opinions about the coup. However, an officer from the licensing office called to warn CTV that it was contravening the terms of its licence and told Yates 'we would prefer you not to use television to express people's opinion' (ibid). CTV 'respected' that request. This incident poses some interesting questions about what understanding policy makers and regulators have about community media's role in the nation's democratic processes and what are the safeguards in Fiji's media legislation to ensure that community media enjoy the same protection from censorship as mainstream media? Unfortunately CTV closed down due to John's failing health and lack of a strong community presence in the station's management. The community media sector continues to grow with radio licences being offered to Christian stations operating in Suva as well as in other centres of Fiji. Unfortunately, local content on these stations is limited as they are largely dependent on taped programming from evangelical broadcasters in the United States. As discussed by the community media practitioners, community media can play an important role in the reconciliation process in post conflict societies for dialog and bridge building between estranged groups.

\section{Conclusion}

How do traditional societies which are struggling to find a crucial nexus between communal and individual rights preserve their communities? How can they employ ICT to strengthen their social networks and allow marginalised voices to be heard? This article demonstrates through various case studies that despite being located on the fringe of the information 
technology boom, it is possible for island communities to engage with ICT for community empowerment and participation at a local level using alternative media models. As a democratising force, the internet and community media can be used by a socially fragmented community in rebuilding its identity through projects of social rehabilitation and healing. ICT can be extended in post-coup Fiji and other post conflict societies in the Pacific for the purpose of reconciliation. For this to happen, local communities must be encouraged to participate in meaningful local content production as an extension of other reconciliation projects. The government should formulate policies and support rural-based projects which would enable ICT adoption by those who can least afford it. To successfully represent their needs and aspirations, local communities must engage in local content development in a selfdirected and culturally appropriate context. Ultimately what gets produced must come from the hearts and minds of the communities themselves.

\section{Note}

1. The study was conducted by the author for her doctoral dissertation and it will be published in a forthcoming book South Pacific Islands Communication: Local and Regional Perspectives (Eds.) Evangelia Papoutsaki \& Usha S. Harris.

\section{References}

Amalgamated Telecom Holdings Ltd. (2002). Annual Report. Suva, Fiji: ATHL

Appadurai, A. (1996). Modernity at large: cultural dimensions of globalisation. Minneapolis: University of Minnesota Press.

Braden, S. (1999). Using video for research and representation: basic human needs and critical pedagogy. Journal of Education Media, 24(2): 117-129.

Castells, M. (2000). The rise of the network society (2nd Edition). Oxford: Blackwell Publishers.

Chand, A., and Leeming, D. (2006). Impact of PFNet services on sustainable rural development. In S. Marshall, W. Taylor \& X. Yu. (Eds.), Encyclopedia of developing regional communities with information and communication technology. Hershey, PA: Idea Group Inc.

Coleman, J. (1988). Social capital in the creation of human capital. American Journal of Sociology. 94-120.

Dagron, A. G. (2001). Making waves: stories of participatory communication for social change. New York: The Rockefeller Foundation.

Deane, J. (2005). Why the media matter: ensuring the world's poorest people have a say. MAZI 5. Retrieved on 2 July 2007 from: www.communicationforsocialchange. org/pdf/why_the_media_matter.pdf

Department of Communications, Information Technology and the Arts. (2005). 
The role of ICT in building communities and social capital: a discussion paper. Canberra: Australian Government. Retrieved on 8 June 21007 www. dcita.gov.au/_data/assets/pdf_file/23737/The_Role_of_ICT_in_Building_ Communities_and_Social_Capital.pdf

Dixit, K. (2000). Exiled to Cyberia: a third world view on the knowledge society. $D+C$ Development and Cooperation No. 4, July/August 2000, p. 15. Retrieved on 3 March 2003 from: www.inwent.org/en

Fiji bloggers get international support after crackdown (2007, May 21). ABC Radio Australia. Retrieved on 28 June 2007 from: www.radioaustralia.net.au/news/ stories/s1928110.htm

Hammond-Thrasher, C. (2007, April 18). 24 hours to go: Fiji bloggers' meeting. Pacific Islands chapter of the Internet Society (PICISOC) Discussion List. PICISOC@picisoc.org.

International Telecommunications Union. (2007). Proposal for a new ITU-D study group 2 question 23/2: 'The unique telecommunication/ICT needs of small island developing states (SIDS)'. Geneva: ITU

Joshi, I. (Ed). (1998). Asian women in the information age: new communication technology, democracy and women. Singapore: AMIC

Meadows, M. et.al. (2007). Community media matters: an audience study of the Australian community broadcasting sector. Brisbane: Griffith University.

Meikle, G. (2002). Future active: media activism and the internet. London: Routledge.

Minges, M. and Gray, V. (2004). Bula internet: Fiji ICT case study. International Telecommunications Union. Retrieved 20 July 2004 from: www.itu.int/ITU-D/ ict/cs/fiji/index.html

Purcell, F. (2007, June 10). Telecentres and sustainability. Pacific Islands Chapter of the Internet Society (PICISOC) Discussion List. PICISOC@picisoc.org.

Purcell, F. and Toland, J. (2002). Information and communication technologies in the South Pacific: shrinking the barrier of distance. Wellington: Victoria University. Retrieved on 10 September 2003 from: www.fdc.org.au/files/toland-2.pdf

Putnam, R. (2000). Bowling alone, New York: Simon \& Schuster.

Robie, D. (2001a). Coup coup land: the press and the putsch in Fiji. AsiaPacific MediaEducator, No 10, January-June, pp. 148-162.

Robie, D. (2001b). Frontline reporters: a students' internet coup. Pacific Journalism Review, 7(1):47-56pp.

Rodriguez, C. (2001). Fissures in the mediascape: an international study of citizens' media. Cresskill, NJ: Hampton Press.

Rolls, S. B. (2002). The impact of new ICT on the media: a community media perspective from the Pacific island region. Paper presented at United Nations Division for the Advancement of Women (DAW) Expert Group Meeting, Beirut, Lebanon, 12 -15 November.

Sagapolutele, F. (2007, April 17). Calling American Samoa: inching closer to fibre optic capabilities. Pacific Magazine. Retrieved on 2 July 2007 from: 
www.pacificmagazine.net/issue/2007/04/17/calling-american-samoa

Samoa, Pacific neighbors sign cable agreement. (2007, June10). Samoa Observer.

Retrieved on 12 June 2007 from: http://pidp.eastwestcenter.org/pireport/2007/ June/06-11-08.htm

Satheesh, P. V. (n.d.). Participation and beyond: handing over the camera. Deccan

Development Society. Retrieved on 2 August 2006 from: www.ddsindia.com/ www/default.asp

Servaes, J., White, S. A., \& Jacobson, T. (Eds.). (1996). Participatory communication for social change. New Delhi: Sage Publications.

Turaganivalu, J. (2003). Personal interview, Ministry of Communications, Suva, Fiji.

White, S. A. (Ed). (2003). Participatory video images that transform and empower, New Delhi: Sage Publications.

White, S. A., Nair, S. K., \& Ascroft, J. (1994). Participatory communication: working for change and development. New Delhi: Sage Publications.

World Bank (n.d.). Social capital for development. Retrieved on 22 August 2006 from: www1.worldbank.org/prem/poverty/scapital/whatsc.htm

Usha Sundar Harris lectures in the Department of International Communication at Macquarie University, Sydney. She has had a varied career in the media industry in Fiji, the US and Australia. She is a strong advocate of community media development and has made innovative uses of media technology to give representation to marginalised communities. Her current research combines participatory action research and ethnography to study the process of participatory video production with rural women in Fiji.

This is a revised version of an article originally published under the title 'ICT for Social and Cultural Capital in Pacific Island Communities.'. In Steward Marshall, Wal Taylor and Xinghua Yu (Eds.) (2006), Encyclopedia of Developing Regional Communities with Information and Communication Technologies. Hershey: Idea Group Inc.

Usha.Harris@scmp.mq.edu.au 